\title{
Militância na cabeça, direitos humanos no coração e os pés no sistema: - lugar social do advogado popular
}

\author{
LAURA D. VON MANDACH*
}

resumo $\mathrm{O}$ presente artigo pretende descrever a atuação do Estado nos conflitos fundiários através de um ator social específico: o advogado popular. A democratização do movimento dos direitos humanos no Brasil não só diferenciou as vítimas em distintos grupos sociais marginalizados, como também profissionalizou seus militantes. Um deles, o advogado popular, defende pequenos produtores envolvidos em conflitos fundiários. Paralela à profissionalização da militância, verificou-se a significativa judiciarização dos conflitos fundiários. A análise dos conflitos no âmbito do Estado considera importante identificar a lógica de cada palco judiciário e, conseqüentemente, a atuação dos atores estatais envolvidos, aqui descrita através da percepção do advogado popular. A autora conclui que embora a profissionalização e a acumulação da experiência coletiva dos advogados tenha resultado em um distanciamento de sua clientela, sua participação no Judiciário fez avançar a reforma agrária.

unitermos Sociologia do direito, advogado popular, direitos humanos, sem-terra, conflitos fundiários. abstract This article describes the role of the state in land conflicts in Brazil, perceived by one specific social actor, the popular lawyer. The democratization of the human rights' movement in Brazil resulted in the differentiation of the victims in distinct marginalized social groups and the militants' professionalization. The popular lawyer, one of the actors of the human rights' movement, defends landless people involved in land conflicts. Within the justice system the land conflict takes place in three different stages: police investigation, penal case and civil action. In each one of these stages the administration of the conflict follows a specific logic. The traditional attitude of the state actors towards the landless people is partial. Nevertheless, the participation of the popular lawyer in the inner judicial conflict represents the beginning of the integration of the landless population's interests in the justice system.

uniterms Sociology of law, popular lawyer, human rights, landless people
O texto com o qual os Estados-membros da Organização das Nações Unidas se comprometeram a proteger os direitos humanos, a Declaração Universal dos Direitos do Homem, adotada pela Assembléia Geral no dia 10 de dezembro de 1948, não é o único docu-

* Doutora em Sociologia pela Universidade de Zurique. mento através do qual os Estados assumiram o compromisso de garantir os chamados " $\mathrm{di}$ reitos humanos". No que se refere ao Brasil, a Constituição Federal de 1988, texto mater do ordenamento jurídico brasileiro, enumera, em suas primeiras páginas, os direitos fundamentais reconhecidos e garantidos pelo Estado brasileiro. 
A lista dos direitos fundamentais que constituem os direitos humanos sempre foi e continua sendo ampliada, incorporando novas dimensões e modelos de direitos tidos como fundamentais. Partindo da experiência européia, cientistas políticos categorizaram os direitos humanos em quatro "gerações": a primeira compreende os direitos de liberdade; a segunda, os de integridade física; a terceira, os de igualdade; e a última geração contempla os direitos sociais. Essa sucessão de "gerações" objetiva descrever a ampliação histórica dos direitos fundamentais em analogia a um modelo de desenvolvimento do Estado que também possui distintas fases: Estado, Estado Constitucional, Estado de Direito e Estado de Bem-Estar Social (Guggenberger, 1989:138)

Não foi só Bobbio, relatando a história dos “direitos humanos", que observou, mesmo depois das grandes transformações sociais, que nenhum Estado alcançou um estágio que tenha tornado obsoleta a luta pelos direitos fundamentais, como sonhou o otimismo iluminista (Bobbio, 1991:355). A luta em prol dos direitos humanos permanece atual em todos os países, por mais "desenvolvidos" que estes sejam. O que diferencia as lutas pela garantia dos direitos fundamentais são suas trajetórias. Em países europeus muitos direitos fundamentais teriam sido incorporados a partir de reivindicações populares. No Brasil, as garantias individuais reconhecidas na Constituição Federal foram introduzidas pelas elites e, posteriormente, descobertas e reivindicadas por grupos sociais específicos (Castañeda, 1996).

1. Guggenberger faz referência a uma teoria da democracia. Com o modelo do Estado Mínimo, que redefine a função do Estado, observa-se que o processo de transformação de Estado Hobbesiano em Estado de BemEstar Social pode ser, se de todo alcançado, a qualquer momento revertido.
Como não foram resultados da mobilização da sociedade civil, os direitos fundamentais assegurados pela Constituição não se difundiram em direção ao corpo das leis comuns e não houve lobby para que as práticas dos agentes estatais aplicadores da lei fossem revistas. Mesmo após o processo de democratização iniciado fim dos anos 70, no sistema de segurança e justiça, os agentes continuam aplicando as leis de maneira parcial "dispensando diferentes tratamentos legais às mesmas infrações, dependendo da situação social ou profissional dos suspeitos" (Kant de Lima, 1996:1). Perceber esta incoerência, o chamado "paradoxo legal brasileiro" (Kant de Lima, 1996:1), e procurar formas para superá-lo, é o que a luta pela real garantia dos direitos humanos deve objetivar.

\section{A Profissionalização DA MilitâNCIA}

Pesquisadores da história recente do movimento em defesa dos direitos humanos têm enfatizado que a mobilização significativa do movimento durante os anos 60 e 70 se deu por parte da classe média, que, no contexto político da Guerra Fria, reivindicava a anistia de presos políticos oriundos desta classe. Com a queda do muro de Berlim e a transição de regimes autoritários para regimes formalmente democráticos, na Europa do Leste como na América Latina, o número dos "presos de consciência" (conceito da Anistia Internacional), as vítimas-alvo do movimento de direitos humanos até então, caiu significativamente.

No Brasil, a partir da própria experiência com a repressão (nos porões da ditadura), os perseguidos teriam se deparado com o "verdadeiro Brasil" (Vargas, 1979). O movimento de direitos humanos decidiu democratizar sua luta, incluindo no rol das vítimas o preso comum, o menino de rua, o pequeno produtor 
e outros representantes de grupos sociais marginalizados (Oliveira, 1995:55).

Apesar da forte repressão contra o ampliado programa desse movimento de direitos humanos, muitos militantes não cederam e profissionalizaram sua atuação. Esse processo resultou em um novo e diferenciado campo de trabalho com assistentes sociais defendendo os direitos dos meninos de rua, professores voltados à formação de adultos analfabetos, advogados lutando pelos direitos fundamentais da população carcerária, dos povos indígenas, dos trabalhadores rurais, posseiros, seringueiros, da população atingida por barragens e outros grupos sociais até então sem representação, ou mesmo ainda sem uma denominação.

No período pós-1985, a luta do militante em prol dos direitos humanos mudou de caráter. Durante o regime militar defendia sua própria classe; em seu engajamento posterior, este militante foi movido por um sentimento de solidariedade para com um grupo social marginalizado e, na medida em que se profissionalizava, o grupo social com qual se solidarizou passou a ser seu cliente.

Um dos atores sociais que se formou neste novo contexto do movimento de direitos humanos foi o advogado que atua na defesa dos interesses dos pequenos produtores sem-terra e seus representantes. O "advogado popular", conforme ele se autodenomina, acompanha as ações civis e penais impetradas por latifundiários e por representantes do Estado contra os pequenos produtores ${ }^{2}$ no contexto dos conflitos fundiários.

2. Devido às suas distintas trajetórias, os pequenos produtores envolvidos nos conflitos fundiários dispõem de recursos materiais e imateriais diferentes (conhecimento profissional, sistema de valores etc.), sendo que a proletarização do trabalho rural e da expropriação da terra - processos iniciados na década de 50 (D'Incao, 1991) - são experiências que eles têm em comum. Neste sentido, trata-se de um grupo social com aspectos tanto

\section{ONIPRESENÇA DO ESTADO, NUNCA MAIS?}

Durante os anos da Guerra Fria o movimento em prol dos direitos humanos, abrindo espaços de afirmação da cidadania, foi visto como um importante contraponto ao Estado onipresente (Fernandes, 1994:17). A atuação dos advogados populares que defendem os interesses dos pequenos produtores sem-terra também pode ser vista como um contraponto neste sentido. O Judiciário, que durante a ditadura teve seus braços atuantes amarrados pelo Executivo, alcançou, nas últimas duas décadas, no contexto dos conflitos fundiários, um papel significativo. Na tentativa de solucionar seus conflitos fundiários, os proprietários rurais têm cada vez mais recorrido aos agentes do sistema de justiça e segurança ${ }^{3}$. Isto se verifica no aumento do número de despejos judiciais que corre paralelamente ao decréscimo das expulsões de pequenos produtores efetuadas por particulares (vide Gráfico 1).

heterogêneos quanto homogêneos. As relações de trabalho dos pequenos produtores são distintas; existe o trabalho assalariado, o arrendamento, a parceria, a posse e a moradia. Cada uma destas relações implica uma dependência específica do empregador e/ou proprietário da terra. A categoria pequeno produtor também engloba o pequeno proprietário - lugar social no qual não existe a ígura do grande proprietário (Moreira, 1997). Finalmente, a categoria pequeno produtor ressalta o momento político da luta por terra, a demanda por redistribuição da propriedade rural destinada à pequena produção. Fora estas razões, os resultados da pesquisa não permitiram mapear as relações entre os advogados e seus clientes de maneira mais diferenciada, sendo que a categoria genérica pequeno produtor é a única utilizada no presente artigo.

3. Mançano Fernandes descreve o processo de "judiciarização" dos conflitos fundiários na região do Pontal de Paranapanema (São Paulo) com uma grande riqueza de dados. Interessante é que nesta região há, fora os conhecidos atores estatais (Polícia, Ministério Público, Judiciário e INCRA), o Instituto de Terras de São Paulo (ITESP), que, com o objetivo de discriminar as terras devolutas do estado, também tem um papel importante nos conflitos fundiários (Mançano Fernandes, 1996:202). 
Gráfico 1: Expulsões e despejos judiciais nos conflitos fundiários (1985-1997)

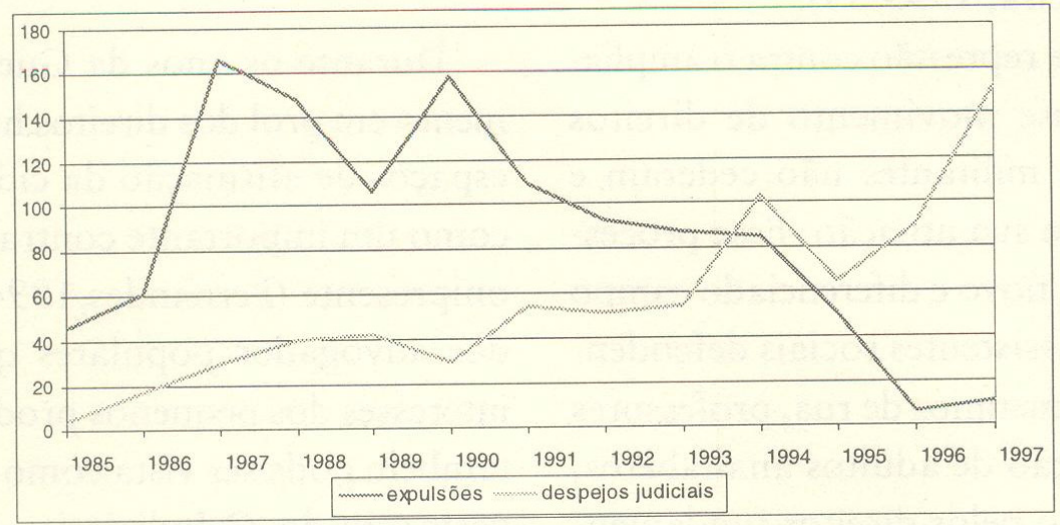

Fonte: Setor de Documentação da CPT (1998).

Pode-se argumentar que a intervenção dos operadores estatais nos conflitos de terra demonstra não só a continuidade de uma onipresença estatal, mas, também, sua inalterada atuação parcial. Enquanto o Judiciário favorece o latifúndio, os operadores estatais reprimem e criminalizam o pequeno produtor semterra por seu envolvimento nos conflitos ${ }^{4}$.

Ao comentar suas próprias estatísticas, a Comissão Pastoral da Terra (CPT) avalia que:

"a queda em geral (...) do número de violências contra a pessoa e, ao contrário, o crescimento em geral das ocorrências contra a posse e a propriedade, com suas importantes exceções, sugerem alguma relação entre estes fenômenos. É certo que o recurso maior ao aparato do Fstado faz reduzir o uso de certas modalidades de violência, digamos, 'privada'. Assim, o número de vítimas de despejo e,

4. A lei e a sua aplicação não podem ser reduzidas a uma ideologia das classes dominantes ou do Estado. Elas também fundamentam as relações produtivas de uma devida sociedade (Thompson, 1987:349), assim como se orientam pela lógica inerente aos textos jurídicos (Bourdieu, 1989:211). No entanto, a parcialidade da Justiça nos casos aqui em análise é claramente uma concretização da continuidade do poder das elites agrárias no Brasil. Segundo Holston (1993), ao longo do século XIX, as elites brasileiras apropriaram-se do campo jurídico, definindo suas regras e as atuações das instituições neste espaço social, sendo que a autonomia posteriormente adquirida pelo Judiciário não interferiu, mas garantiu os interesses das elites. principalmente, o de ameaçados de despejo judicial tiveram os maiores aumentos, enquanto caiu drasticamente o de vítimas de expulsão, confirmando a tendência dos últimos anos de utilizar menos este recurso quando o Judiciário, através das liminares de despejo, cumpre o papel de defender o latifúndio" (CPT, Notícias da terra, 4/7/1997).

\section{Os DifERentes Palcos dos Conflitos FUNDIÁRIOS}

De forma esquemática, o conflito fundiário aqui abordado tem como objeto a propriedade rural. As partes que por este objeto conflitam são o pequeno produtor organizado e o grande proprietário. O pequeno produtor alega ter direito à posse por tê-la detido por um longo período; ou afirma ter um direito genérico à terra, conforme a reforma agrária estabelecida na Constituição Federal de 1988, afirmando também não ter alternativa para sua sobrevivência, senão a pequena produção. $\mathrm{O}$ proprietário alega ter o domínio da terra, não aceitando a presença dos pequenos produtores em seu empreendimento rural, que afirma ser produtivo.

No momento em que o proprietário e o pequeno produtor, qualificados como partes, decidem recorrer ao Judiciário, o conflito en- 
tre eles é intermediado por peritos, juízes, promotores e advogados, principais atores do campo jurídico ${ }^{5}$. Não socializados com as regras desse campo, as partes não mais se confrontam diretamente e são submetidas aos procedimentos neste utilizados.

A administração do conflito no campo jurídico reflete a concorrência pelo monopólio da construção de verdades (Bourdieu, 1989: 212) e desdobra-se em vários processos e procedimentos que tramitam em, no mínimo, três palcos judiciais. O inquérito policial procede na Polícia Civil; a ação possessória e o processo penal na Justiça Estadual; enquanto a ação de desapropriação é movida por representantes do INCRA ${ }^{6}$ durante sua fase administrativa e, posteriormente, em sua fase judicial, procede na Justiça Federal.

Em todos os palcos aqui abordados o conflito é administrado de maneira específica os regimes de produção de verdades são distintos. O inquérito policial é inquisitorial (monológico e sigiloso), e visa apurar crimes cometidos pelos produtores rurais. A ação penal é resultado do inquérito policial. Embora ela garanta o contraditório e a publicidade dos atos judiciais, vários de seus elementos têm caráter inquisitorial e inquisitivo. Conforme o Código do Processo Penal brasileiro (1941), a ação penal pretende descobrir a verdade "real". Para formar seu "livre convencimento", o juiz deve trazer aos autos tudo o que pensa interessar ao processo (Kant de Lima, 1997:174).

Imbuídos de outra lógica, os processos civis - a ação possessória e a de desapropria- ção - visam a descoberta da verdade "formal". São as partes que trazem as provas ao juiz que as incorpora aos autos. Não conseguindo provar que eles detêm o direito à posse, a ação possessória objetiva reintegrar o proprietário, despejando os pequenos produtores da propriedade em questão. A ação de desapropriação, por sua vez, é iniciada após decreto do Poder Executivo, e tem como objeto a negociação da quantia oferecida pela União ao ex-proprietário pela perda de sua propriedade rural.

Além disso, os palcos do conflito fundiário distinguem-se pelos atores estatais envolvidos. Enquanto no processo civil o promotor participa pouco, na ação penal ele detém a acusação e é o “dono" deste processo. Na ação possessória, as partes são o proprietário e o pequeno produtor e na ação de desapropriação representantes do INCRA negociam a indenização pela desapropriação da terra com o ex-proprietário. Já na ação penal, o proprietário não participa; as partes são o promotor e o pequeno produtor.

Antes de ser transportado para o campo jurídico, o conflito fundiário trava-se, em geral, na fazenda. Seguindo ordens, empregados e seguranças dos fazendeiros ameaçam e tentam expulsar os posseiros, pequenos arrendatários, ocupanites da terra. Destroem suas casas e roças e envenenam seus animais. Os pequenos produtores deixam a terra, migrando para uma cidade próxima. Os casos envolvendo posseiros e pequenos arrendatários são concluídos desta forma ${ }^{7}$.

7. Margarida Moura descreve com propriedade o processo de expulsão dos pequenos produtores a partir dos anos 80 no Vale do Jequitinhonha (Minas Gerais), diferenciando violências materiais, simbólicas e físicas sofridas pelos pequenos produtores até serem postos "na definitiva" pelos donos da terra (Moura, 1986:101). 
Quando os posseiros se organizam e se negam a deixar a terra, ou quando eles retornam, dias depois de terem sido expulsos e/ ou despejados, o proprietário muitas vezes recorre ao Judiciário, requerendo ao juiz a abertura de uma ação possessória contra os “invasores".

Em tese, a ação possessória é uma figura jurídica utilizada por aquele que detém a posse, exercendo uma atividade econômica no local. Muitos proprietários, no entanto, não cultivam sua propriedade rural e não moram na fazenda ou mesmo na região, não detendo, assim, a posse. Conforme Dutra, engajado advogado popular, em seu artigo "O Espaço dos Privilegiados", esta "distorção processual" - a preferência pela ação possessória ao uso da ação reivindicatória, própria para a defesa da propriedade - teria vários motivos. A ação reivindicatória não permite a concessão de liminares e seu trâmite é demorado, enquanto a ação possessória permite que o litígio seja liquidado através de uma simples medida provisória, a liminar. Além disto, na ação reivindicatória, que é a mais demorada, o proprietário seria obrigado a indenizar os trabalhadores pelas suas benfeitorias, gastos evitados com despejos, quando em geral as benfeitorias são destruídas. Dutra acrescenta que, nesta ação, o proprietário também corrc o risco de não convencer o juiz que ele de fato detém a posse e o domínio. Com o rito sumário da ação possessória, o grileiro, falso proprietário, evita a intervenção dos órgãos fundiários (Dutra, 1992:35) .

No seu requerimento de abertura da ação possessória, o proprietário solicita ao juiz que este lhe conceda uma liminar e que ordene de

8. Dutra critica a atuação dos juízes nas ações possessórias: "O ajuizamento das ações é feito de maneira irregular, as partes não são devidamente qualificadas e as liminares concedidas não são fundamentadas" (Dutra, 1992:35). imediato o despejo a ser efetuado com reforço policial. Às vezes o autor sugere o destacamento da Polícia Militar a ser chamado.

Com a concessão da liminar a fazenda retorna a ser palco do conflito fundiário. $\mathrm{O}$ oficial de justiça, muitas vezes acompanhado pela Polícia Militar, dirige-se à propriedade, lê para os pequenos produtores a determinação judicial e os faz entender que eles têm de se retirar. Quando obedecido, o conflito é ali concluído. As famílias saem da terra e migram. Muitos conflitos fundiários terminam no momento do despejo judicial.

Quando os pequenos produtores colocamse contra a determinação judicial no momento do despejo, ou voltando para a propriedade dias depois, o conflito toma um novo rumo. A atitude dos trabalhadores é registrada pelos oficiais de justiça e, diante do não-cumprimento da liminar, o juiz notifica a Polícia Civil, que assim motivada ou por iniciativa própria, instaura um inquérito policial indiciando os trabalhadores por desobediência ou resistência. Concluído o inquérito, ele é remetido ao promotor que, baseando-se neste, elabora e apresenta a denúncia ao juiz. Aceitando-a, o magistrado instaura a ação penal. No final desta ação, os trabalhadores muitas vezes são condenados e penalizados pelos crimes a eles imputados. A partir do momento em que o juiz aceita a denúncia do promotor, que se deu em decorrência da ação civil, as duas ações tramitam em paralelo, mas independem uma da outra. Uma eventual solução do conflito na área civil não afeta o rumo da ação penal. $\mathrm{O}$ pequeno produtor entra no conflito fundiário como parte de uma ação civil, litígio no qual ambas as partes participam, mas, em segui$\mathrm{da}$, é forçosamente levado para outro palco do conflito, onde o Estado termina por penalizá-lo pela sua participação no conflito. Para o Movimento dos Trabalhadores Rurais SemTerra (MST), esta realidade significa que: 
"Em 90\% das ocupações do MST têm despejos. Em 60\% dos casos onde há ocupações, há um processo criminal, e em $90 \%$ onde há ocupações têm um inquérito policial. (...) São em torno de 60 processos que tramitam contra membros do MST" (entrevista com um representante do setor de direitos humanos do MST, em julho 1998).

Em geral, logo após as ocupações de pequenos produtores sem-terra organizados, o INCRA é solicitado para vistoriar a fazenda com o objetivo de avaliar se a propriedade cumpre sua função social e, na negativa, propor a sua desapropriação para fins de reforma agrária, conforme previsto na Constituição. A ação de desapropriação - o terceiro palco judiciário do conflito - tem duas fases. A primeira, a administrativa, inclui a vistoria do INCRA e a avaliação do valor da fazenda e de suas benfeitorias, concluída com o decreto de desapropriação assinado pelo Presidente da República. A segunda fase, o processo judicial, procede na Justiça Federal Regional. Neste âmbito, o proprietário não pode mais recorrer da decisão de desapropriação, mas contestar o valor da indenização fixada pela União. Esta ação é concluída quando o ex-proprietário é indenizado e o juiz concede a emissão de posse a INCRA, permitindo que seus agentes assentem as famílias sem-terra cadastradas na propriedade.

Mesmo depois da desapropriação efetivada, quando o Presidente assina o decreto de desapropriação, ato que excepcionalmente pode ser revertido - exclusivamente com base numa decisão do Supremo Tribunal Federal, a ação possessória continua tramitando na Justiça Estadual. O requerimento do INCRA, formulado ao juiz para ser incluído na ação possessória como parte, e para que o magistrado remeta o processo à Justiça Federal, na maioria dos casos é negado. A primeira instância da Justiça Estadual, sistematica- mente, ignora a existência da ação de âmbito federal ${ }^{9}$.

Seria possível sustentar que este conflito fundiário termina com o arquivamento das ações possessória e de desapropriação. Mesmo se este for o caso, em um outro palco é dado prosseguimento ao conflito. A ação penal contra os trabalhadores não cessa. Mesmo depois da desapropriação da terra, o proprietário indenizado e a ação civil arquivada, o trabalhador continua rotulado como acusado. O Estado pode investir no pequeno produtor, assentando-o na propriedade, concedendo-lhe crédito e assistência técnica, mas isto não priva o pequeno produtor de ser condenado e até preso devido à sua "desobediência" e à sua "resistência".

\section{O Advogado Popular: Transeunte dos Diversos Mundos}

O lugar social do advogado popular é bastante peculiar. Ao mesmo tempo em que é um profissional e um opositor do sistema político vigente no exercício de sua atividade, ele atua dentro do sistema judiciário, conhecendo as regras do jogo, e a utilização do ordenamento jurídico e suas práticas informais. Por ter os pequenos produtores sem-terra organizados como clientes, o advogado popular enfatiza a importância da defesa dos direitos e deveres coletivos, direitos e garantias fundamentais garantidos na constituição. Ao mesmo tempo que se empenham na auto-aplicação de direitos garantidos pela Constituição, os advogados-militantes - como os advogados dos autores das ações civis impetradas contra seus clientes - também recorrem ao Código Civil,

9. Há exceções: no Paraná, uma portaria expedida pelo Tribunal de Justiça prevê que, no caso de desapropriação de uma propriedade rural para fins de reforma agrária, a Justiça Estadual deve remeter a ação possessória à Justiça Federal. 
sempre ressalvando tratar-se de um corpo de leis há muito tempo superado ${ }^{10}$.

Atuando no campo jurídico, o advogado popular tem de relacionar-se, e ele o quer, ao menos razoavelmente bem, com os agentes estatais, objetivando o êxito profissional. Saber relacionar-se com o juiz, o promotor e o delegado significa apropriar-se da linguagem do poder.

O advogado popular também faz parte de um mundo sociopolítico, no qual ele se relaciona com seus clientes e com representantes da sociedade civil, políticos, sindicalistas, representantes da Igreja, da imprensa, muitos deles tidos pelo advogado como indispensáveis parceiros. É com este mundo que ele deseja se identificar, compartilhando os mesmos valores, reivindicando junto com os sem-terra a reforma agrária, uma justa distribuição de renda etc.

Ao mesmo tempo que o advogado popular transita nestes dois mundos, não faz parte deles. Em geral oriundos da classe média urbana, os advogados não foram socializados no meio rural, e muitas vezes desconhecem a realidade da pequena produção familiar. $\mathrm{O}$ que faz a ponte entre ele e o pequeno produtor não é um lugar social comum, mas um sentimento de solidariedade política. Por outro lado, mesmo que ele compartilhe um lugar social comum com os agentes do sistema judiciário, o advogado popular no contexto rural esforça-se em distanciar-se destes, tendo outro estilo de vida, freqüentando um meio cultural diferente.

10. "Apesar de todos os avanços tecnológicos, inclusive no Brasil, a maioria dos julgadores continua interpretando a propriedade com a visão do século XVII, expressa num código obsoleto de 1916, que é o Código Civil. Ou seja, a visão e conceito de propriedade estacaram no tempo" (Dutra, 1992:40).

\section{PercepÇÕes dos Advogados Populares}

Quando, na qualidade de pesquisadora, estive acompanhando o trabalho da assessoria jurídica da CPT na Paraíba, conheci vários advogados que defendem os interesses de pequenos produtores na Justiça e que se tinham articulado como um grupo, "trocando figurinhas" via Internet e, há pouco tempo, tinham criado a Rede Nacional Autônoma dos Advogados Populares. Dado meu interesse pela atuação dos diversos atores do sistema de segurança e justiça, participei do III Encontro Nacional da Rede. Diante da oportunidade de encontrar advogados atuando em diferentes regiões do País, tive curiosidade em analisar como, nos conflitos fundiários, estes percebem a atuação dos agentes estatais; do juiz, do promotor e das polícias militar e civil. Elaborei um questionário que apresentei durante o encontro ${ }^{11}$.

\section{Resultados De uma Pesquisa}

Questionados sobre quais tipos de ações judiciais eles acompanham em decorrência de conflitos fundiários, os dez advogados assinalaram acompanhar ações civis e penais. Cinco advogados também mencionaram que atuavam em outras áreas, acompanhando ações trabalhistas e eleitorais, o que indica uma experiência no meio sindical e político. Grande foi a variação no número das ações decorrentes de conflitos fundiários acompanhadas pelos respondentes. Enquanto a metade dos respondentes atuava na faixa de $20 \mathrm{e}$

11. Pedi que um advogado por escritório de advocacia preenchesse o questionário, evitando que os dados quantitativos fossem distorcidos. Dos 26 questionários distribuídos entre os 83 participantes do encontro, recebi, posteriormente, pelo correio, dez de volta, $38 \%$ do total. Em conversa com dois advogados soube que seus questionários foram extraviados pelo correio. 
35 casos, três acompanhavam somente alguns casos. Para a maioria, os casos decorrentes de conflitos fundiários não chegavam a $1 / 4 \mathrm{de}$ seus casos, sendo que, para os escritórios de advocacia, a assessoria jurídica oferecida aos pequenos produtores não representava uma atividade principal.

A maioria dos respondentes atuava no Paraná12, São Paulo, Santa Catarina, Rio Grande do Sul, Espírito Santo, Bahia e Rondônia ficaram representados com um advogado/escritório cada. Enquanto os advogados da Bahia e de Rondônia atuavam em sete comarcas, os do Paraná acompanhavam processos em três ou quatro comarcas cada. Sete comarcas representam um cotidiano árduo: demoradas e freqüentes viagens de uma comarca para a outra.

Os advogados que acompanhavam ações penais defendiam juntos, em 32 ações, em torno de 320 pessoas indiciadas ou acusadas na Justiça. A maioria dos crimes referia-se a formação de bando ou quadrilha, lesão corporal, homicídio e esbulho possessório. O repertório das acusações parece ser o mesmo em todo o País ${ }^{13}$. Conforme a maioria dos respondentes, é a polícia que instaura o inquérito por iniciativa própria. Dois advogados informaram que, a partir de suas experiências, todos ou grande parte dos inquéritos foram instaurados por requerimento do juiz a pedido dos proprietários.

Quatro respondentes assinalaram que acompanham casos de homicídio na qualidade de advogados de defesa ${ }^{14}$. Dois ocorreram em

12. A numerosa presença de advogados do Paraná no encontro nacional reflete-se aqui. Haja vista que a articulação da rede neste Estado é avançada, o número de advogados que participa da rede é alto, suas reuniões freqüientes.

13. Fora os delitos acima enumerados, também foram assinalados os crimes de resistência, desobediência, dano e incêndio.

14. A atuação acusadora representa a exceção. Só um dos
1997, e ainda estão em fase de inquérito policial. Um ocorreu em 1982 e está em fase final de instrução. Em um caso ocorrido em 1989, recorreu-se da sentença de primeira instância. Entre os poucos casos concluídos, há os que levaram à condenação e à absolvição dos réus. Respostas que mostram que a morosidade judicial também funciona em prol dos interesses dos pequenos produtores acusados, e comprovam êxitos na atuação dos advogados.

A área civil parece constituir-se como um palco judiciário mais importante do que aquele constituído pela área penal. Os respondentes acompanham quase quatro vezes mais ações civis que penais, sendo que $91 \%$ das ações civis são ações possessórias. Conforme os respondentes, os autores das ações nunca deixam de requerer uma liminar de reintegração de posse; um requerimento que os juízes, também conforme a maioria dos respondentes, deferem quase sempre. Da mesma forma os juízes, nas liminares, quase sempre requerem reforço policial para fazer valer as reintegrações de posse. Conforme seis entre oito respondentes, os juízes, nestas ações, sempre, ou muitas vezes, dão ganho de causa ao autor. As respostas indicam uma atuação uniforme e coerente por parte dos juízes. A maioria dos magistrados defere as liminares, quase sempre requerer do reforço policial para seu cumprimento $^{15}$.

Ao referirem-se às declarações verbais dos magistrados, os respondentes descrevem os

respondentes atua também como assistente de acusação. Trata-se de um caso ocorrido em 1995 no qual 26 acusados, proprietários de fazenda, policiais militares e pistoleiros estão sendo acusados por homicídio. $\mathrm{O}$ processo encontra-se no final da fase de instrução.

15. Não há unanimidade no que se refere à realização de uma audiência de justificação prévia. A lei prevê, na ação possessória, uma audiência no início do processo objetivando um acordo entre as partes. Conforme as respostas, há desde juízes que nunca a realizam, como juízes que muitas vezes convocam as partes para uma audiência deste tipo. 
juízes como atores sensibilizados com a situação dos sem-terra. Em suas declarações públicas, defendem a garantia dos direitos humanos e dizem-se preocupados com uma prestação jurisdicional efetiva à população. Levando em conta somente o comportamento instrumental dos magistrados, os respondentes afirmaram que poucos são realmente sensibilizados. A maioria elabora despachos e sentenças desfavoráveis aos sem-terra. O juiz não sensibilizado não requer ao Ministério Público que este se pronuncie sobre o litígio, como também ignora o INCRA, impedindo que este último seja parte do processo, mesmo tendo manifestado interesse pela área e avaliado a propriedade rural como não produtiva.

Vários respondentes criticaram os juízes por não negociarem com os atores envolvidos nos conflitos fundiários, visto que, não os reunindo, os magistrados inviabilizam soluções pacíficas para os conflitos, deferindo a liminar sem qualquer consulta prévia. Do outro lado, o comportamento dos juízes sensibilizados, visto como ideal, é descrito por um dos advogados da seguinte forma:

“Ele, num primeiro momento, tão logo há a propositura de ação possessória com pedido de liminar, manda primeiramente oficiar ao INCRA, para que o mesmo manifeste se tem interesse ou não sobre a área contenciosa; após a resposta deste, às vezes, é realizada uma reunião com todos os envolvidos para uma conciliação".

Esta última audiência de conciliação, conforme o respondente citado, não deve ser confundida com a de justificação. A reunião de conciliação, conforme outro respondente, já fora realizada na residência de um magistrado.

Salvo os juízes sensibilizados, negociadores, e os não-sensibilizados, os que, na fala dos respondentes, aparecem nas colunas sociais, há também um outro juiz que, por pas- sividade, protela os processos, não assumindo, assim, uma posição diante do conflito.

Tal como no caso dos juízes, a atuação de muitos promotores é percebida pelos respondentes como apresentando uma disjunção entre postura e prática. Segundo os questionados, o promotor, que "adora festas da sociedade e aparecer nas colunas sociais", elabora pareceres favoráveis às liminares de reintegração de posse e oferece denúncias criminais contra líderes, sempre tendo como base teses jurídicas superadas. Este promotor estaria, ainda na opinião dos respondentes, comprometido com o latifúndio, ao mesmo tempo em que legitima sua atuação conservadora diante dos advogados dos sem-terra manifestando o entendimento de que ele teria de agir discretamente e que, ao contrário, muitos colegas promotores estariam, na verdade, fazendo política. Este tipo de promotor é, conforme os respondentes, extremamente formal: faz questão de demonstrar autoridade, mas sempre trata bem os advogados.

Para os respondentes, os promotores não estão condenados a ter uma atitude conservadora. Podem optar por linhas progressistas ou conservadoras existentes no seio da corporação. Segundo eles, os promotores da "linha progressista" elaboram pareceres contrários à desocupação, assumem a defesa de certos bens jurídicos, como a "dignidade humana", procurando proteger interesses difusos e coletivos.

Mesmo a avaliação dos respondentes sendo negativa - a maioria dos juízes e dos promotores em suas manifestações processuais desfavorecem os interesses dos sem-terra-, as descrições da atuação destes operadores jurídicos provam que há um comportamento alternativo tido como ideal pclos advogados. Existe o juiz que convida os envolvidos à sua casa para resolver o conflito, e existe o promotor que se coloca ao lado dos sem-terra, desfavorecendo os interesses do latifundiário. 
A parcialidade da Polícia Civil está, na opinião dos respondentes, mais do que configurada. Ela se dá com o tratamento diferenciado que os agentes policiais dispensam aos sem-terra e aos proprietários. Estes últimos são tratados com "deferência". Denunciam ainda que dos fazendeiros os agentes policiais aceitam auxílios (veículos e o acompanhamento de "empregados" - jagunços - para comparecer aos acampamentos), e que os sem-terra, especialmente aqueles que pertencem ao MST, são vistos com os olhos dos fazendeiros, ao mesmo tempo em que o movimento é percebido como um inimigo militar. A Polícia Civil favoreceria os proprietários, não registrando o conflito para efeito de inquérito. Quando instaurados, os inquéritos policiais seriam conduzidos de maneira tendenciosa, como um respondente afirma: "a polícia nunca procura apurar os fatos, mas, apenas, o trabalho político dos integrantes do MST".

$\mathrm{Na}$ perseguição e repressão aos movimentos próprios é tido como muito comum o procedimento da Polícia Civil de fazer uso da violência física (tortura etc.), valendo-se inclusive de práticas de guerra.

A Polícia Militar, comparada à Polícia Civil, mais precisamente no que se refere a atuação nos conflitos fundiários, é vista de maneira menos negativa. Enquanto os respondentes são unânimes quanto à atitude parcial da Polícia Civil, somente a metade deles vêm a Polícia Militar sendo sempre parcial nos conflitos fundiários. Há o consenso de que os despejos, sempre ou quase sempre, são efetuados pelos agentes mediante extrema violência, típica de ações de choque, mas alguns advogados avaliam que os policiais militares intervêm nos conflitos obedecendo a ordens e, assim, culpam o mandante, neste caso, o juiz ${ }^{16}$.

16. Quando a Polícia Militar investiga, seus agentes são criticados da mesma forma que os da Polícia Civil. Um
$\mathrm{Na}$ situação pré-despejo, os policiais militares parecem sentir-se inseguros e ameaçados. Um respondente relata que, na iminência de um despejo, percebeu que alguns estavam preocupados com a possibilidade de terem de valer-se da força contra os sem-terras, que eram a maioria. Há também situações em que a Polícia Militar, alegando falta de efetivo, deixa de intervir na área de conflito, mesmo tendo sido convocada. Este comportamento é criticado por um respondente porque deixa os trabalhadores "expostos à sanha dos jagunços".

Os advogados responsabilizam individualmente a maioria dos agentes judiciários por suas atitudes parciais. Se o juiz, o delegado e o promotor quisessem, poderiam ter uma postura mais sensível com o pequeno produtor. A superestimação do poder decisório dos agentes - sempre delimitado pelo ordenamento jurídico e suas interpretações dominantes faz parte do discurso do advogado. Motiva os profissionais, no seu engajamento, a mudar as formas dominantes de interpretação dos textos jurídicos nos casos de conflitos fundiários visando um "direito alternativo".

Em suas atividades de advocacia, prestadas aos pequenos produtores, os respondentes têm percebido como parceiros representantes da sociedade civil e agentes do Estado que apóiam a causa dos sem-terra. Questionados sobre quem são seus parceiros, os advogados indicam representantes da Igreja, da imprensa, dos sindicatos e membros de redes e associações, das quais eles mesmos fazem parte. Os representantes do Legislativo, em todos os níveis, principalmente os deputados estaduais, parecem contribuir de maneira significativa. Já na esfera estatal, os parceiros não são numerosos. Os agentes estatais mais vezes assi-

dos respondentes relata: "hoje temos conhecimento da existência da P-2 em nossa cidade; esta instituição ilícita estava voltada para a desmoralização e incriminação dos sem-terra. Telefones grampeados etc.". 
nalados como parceiros foram os representantes do Ministério Público, os procuradores do INCRA e professores de universidades. Os parceiros contribuem de diferentes formas com o trabalho dos advogados: os deputados denunciando casos e negociando para encontrar soluções para os conflitos; os jornalistas divulgando fatos e antecipando informações na mídia; os membros da Igreja contribuem, dentre muitas outras atividades, formando comissões; as redes e associações, das quais os respondentes participam, têm um papel importante na "formação cultural" dos advogados; os três agentes estatais tidos como parceiros e os promotores do Ministério Público contribuem relacionando os advogados com outros promotores; os procuradores do INCRA prestando informações acerca das propriedades em questão e os professores de universidades disponibilizando material bibliográfico e possibilitando aos advogados maior qualificação profissional.

Juntos, os respondentes acompanhavam 12.362 famílias de pequenos produtores na Justiça, sendo que quatro acompanhavam exclusivamente famílias do MST (7.042 famílias) ${ }^{17}$. Na defesa dos sem-terra na Justiça, todos os advogados populares afirmaram enfrentar dificuldades. Questionado-os, sobre quais seriam as dificuldades mais sérias, notase que os respondentes têm uma visão bastante similar: a situação financeira, a atuação parcial dos juízes e a falta de apoio no seio da própria classe.

17. Questionados se "seus" pequenos produtores já moravam na área por eles reivindicada antes da ocupação, as respostas diferiram muito - um indicativo de como em cada região a relação do pequeno produtor com a terra por ele reivindicada se diferencia. Dois advogados responderam que nenhum dos reivindicantes morou na propriedade anteriormente ao conflito; dois avaliam que $5 \%$ dos trabalhadores já moravam na área; e outros dois disseram que todos os seus clientes são posseiros, antigos moradores e produtores na área reivindicada.
Quanto à questão financeira, alguns respondentes alegaram passar por dificuldades devido à inexistência de remuneração pelo trabalho jurídico. Um deles descreve a falta de infra-estrutura dos movimentos para bancarem as despesas com diárias e custas processuais, obrigando-os à dedicação de trabalho em outras áreas do direito para garantir a sobrevivência pessoal e o funcionamento do escritório.

Enquanto a parcialidade dos delegados e promotores é assinalada, uma ou duas vezes, como um obstáculo ao trabalho de advocacia dos respondentes, a atuação dos juízes é alvo da crítica de todos, e vista como um importante empecilho para o trabalho de assessoria jurídica. Os juízes são descritos como parciais, desinteressados, despreocupados, alimentando preconceitos e reforçando a morosidade da Justiça. Os juízes tratam os conflitos de terra como casos de polícia e, na qualidade de "intérpretes da lei", aplicam-na sempre na "ótica da classe dominante", "na defesa cega e inconseqüente do direito de propriedade".

A terceira dificuldade mais apontada pelos respondentes foi a falta de apoio no seio de sua própria classe/categoria profissional. Ao lado dos advogados do mainstream os respondentes vêem-se numa posição marginal e descrevem os outros advogados como sendo parciais. Um respondente alega sofrer discriminação profissional. Também foi mencionada a falta de incentivo por parte da OAB.

\section{CONCLUSÃO}

Após os cinqüenta anos de Declaração Universal dos Direitos Humanos, a luta pela garantia dos direitos fundamentais permanece atual em todos os países. No Brasil, visa a superação do "paradoxo legal brasileiro" uma ordem constitucional igualitária aplicada de maneira hierárquica pelo sistema judicial (Kant de Lima, 1996:1). 
O ator social em questão, o advogado popular, que defende os pequenos produtores sem-terra na Justiça, tem consciência deste paradoxo. À medida que se apropria da linguagem do poder, atuando no campo jurídico, e que compartilha valores de justiça social com grupos sociais marginalizados, fazendo valer direitos fundamentais, individuais e coletivos, conquistando agentes do sistema judiciário para aplicar estes direitos, ele se torna um importante mediador entre diferentes realidades e lógicas.

Os frutos desta mediação não são fáceis de colher. Depois do regime militar, o engajamento do advogado popular mudou de caráter. Houve um distanciamento do militante em relação à causa, resultado de sua profissionalização e da distância social existente entre ele e seus clientes, hoje parcialmente reconhecidos como vítimas de violação dos direitos humanos. Outro freio no engajamento do advogado-militante é seu knou-hou, muitas vezes não recompensado materialmente. $\mathrm{E}$, finalmente, o que também pode ser visto como um empecilho é o lugar social do advogado popular. Ele pouco se identifica com seu mundo profissional, nem se encaixa na realidade de seus clientes. Há também obstáculos que foram postos de lado. À medida que os advogados populares se profissionalizaram e se especializaram, com escritórios autônomos, e têm-se articulado como um grupo social, possível e facilitado, devido à mobilidade e aos novos meios de comunicação, eles têm conseguido somar esforços e dispõem hoje de um saber, produto de experiências conjuntas. Trata-se de uma mobilização silenciosa e sutil, que pode ser vista como importante contraponto em relação à onipresença do Estado nos conflitos fundiários, que é, citando um dos advogados, "capaz de fazer avançar a luta pela reforma agrária”.

\section{BIBLIOGRAFIA}

BOBBIO, Norberto et al. Dicionário de Política. Brasília: Editora da Universidade de Brasília, 1991.

BOURDIEU, Pierre. O Poder Simbólico, Lisboa: Difel, 1989.

CASTAÑEDA, Jorge. "As duas faces de uma América injusta”. In: Jornal do Brasil, Caderno Idéias. Rio de Janeiro, p. 4, 31 ago. 1996.

D’INCAO, Maria Conceição. "A experiência dos assentamentos: contribuição ao debate político da reforma agrária". In: Lua Nova, n. 23. São Paulo: Marco Zero, 1991.

DUTRA, Domingos. “O Espaço dos Privilegiados”. In: Cadernos da CPT: CPI da Violência no Campo. Maranhão: Tempos Novos, 1992.

FERANDES, Rubem César. Privado porém público: o terceiro setor na América Latina. Rio de Janeiro: Relume-Dumará, 1994.

GUGGENBERGER, Bernd. "Demokratietheorie". In: NOHLEN, Dieter (org.) Pipers Wörterbuch zur Politik. München/Zürich, vol. 1, 1989. p. 130-139.

KANT DE LIMA, Roberto. A polícia da cidade do Rio de Janeiro. Seus dilemas e paradoxos. Rio de Janeiro: Forense, 1996.

KANT DE LIMA, Roberto. "Polícia e exclusão na cultura judiciária”. In: Tempo Social 9 (1), 1997. p. 169-183.

MANÇANO FERNANDES, Bernardo. MST - Movimento dos Trabalhadores Rurais Sem-Terra. Formação e Territorialização em São Paulo. São Paulo: Hucitec, 1996

MOREIRA, Emília e TARGINO, Ivan. Capítulos de Geografia Agrária da Paraíba. João Pessoa: UFPB, 1997.

MOURA, Margarida Maria. Os deserdados da terra. Rio de Janeiro: Bertrand, 1988.

OLIVEIRA, Luciano. Imagens da Democracia. Os Direitos Humanos e o Pensamento Político da Esquerda no Brasil. Recife: Pindorama, 1995.

THOMPSON, E. P. Senhores e caçadores. Rio de Janeiro: Paz e Terra, 1987.

VARGAS, Índio. Guerra é Guerra. Rio de Janeiro: CODERCRI, 1979. 